\title{
The influence of Low-Temperature Food Waste Biochars on Anaerobic Digestion of Food Waste
}

\author{
Kacper Świechowski ${ }^{1, *}$, Bartosz Matyjewicz ${ }^{1}$, Paweł Telega ${ }^{1}$ and Andrzej Białowiec ${ }^{1}$ \\ 1 Department of Applied Bioeconomy, Wrocław University of Environmental and Life Sciences, 37a \\ Chełmońskiego Str., 51-630 Wrocław, Poland; kacper.swiechowski@upwr.edu.pl (K.Ś); 110829@stu- \\ dent.upwr.edu.pl (B.M.); pawel.telega@upwr.edu.pl (P.T); andrzej.bialowiec@upwr.edu.pl (A.B.) \\ * Correspondence: kacper.swiechowski@upwr.edu.pl
}

\begin{abstract}
The proof-of-the-concept of application of low-temperature food waste biochars for the anaerobic digestion (AD) of food waste (the same substrate) was tested. The concept assumes that residual heat from biogas utilization may be reused for biochar production. Four low-temperature biochars produced under two pyrolytic temperatures $300^{\circ} \mathrm{C}$ and $400{ }^{\circ} \mathrm{C}$ and under atmospheric and 15 bars pressure with 60 minutes retention time were used. Additionally, the biochar produced during hydrothermal carbonization (HTC) was tested. The work studied the effect of a low biochar dose $\left(0.05 \mathrm{~g}_{\mathrm{BC}} \times\right.$ g $_{\text {TSsubstrate }}{ }^{-1}$, or $\left.0.65 \mathrm{gBC}_{\mathrm{BC}} \mathrm{L}^{-1}\right)$ on $\mathrm{AD}$ batch reactors' performance. The biochemical methane potential test took 21 days and the process kinetics using the first-order model were determined. The results showed that biochars obtained under $400^{\circ} \mathrm{C}$ with atmospheric pressure and under HTC conditions improve methane yield by $3.6 \%$. It has been revealed that thermochemical pressure influences the electrical conductivity of biochars. The biomethane was produced with a rate (k) of 0.24 $\mathrm{d}^{-1}$, and the most effective biochars increased the biodegradability of FW to $81 \%$ in comparison to variants without biochars $(75 \%)$.
\end{abstract}

Keywords: Methane fermentation; biogas; biomethane; biochar; pyrolysis; hydrothermal carbonization; biochemical methane potential; biogas production kinetics.

\section{Introduction}

\subsection{Background}

The implementation of circular economy induces the new approaches of closing the loops of material and energy flows within the systems, including the new solutions for food waste management. The high biodegradability and high biogas potential of food waste may be utilized for both biogas and organic fertilizer production. The biogas yield may be enhanced and the fertilizer quality may be improved by the addition of biochars derived from food waste. It may bring added value to food waste, a component of municipal solid waste (MSW) sustainable management. Progressing economic development is conducive to an increase in waste production. MSW causes environmental problems such as water, air, and soil pollution, loss of biodiversity, and resource depletion, and over-use of land [1]. To counteract the negative waste effects and to counteract resource depletion, the European Union (EU) goes to a circular economy, where waste becomes a new resource. According to the directive 2008/98/EC on waste [2], EU states should move towards a circular economy by achieving targets for preparing, reusing, and recycling MSW. These targets were set to a minimum of $55 \%, 60 \%$, and $65 \%$ (by weight) by 2025,2030 , and 2035, respectively [2]. To meet the directive targets and goals of the circular economy, the Council of the European Union adopted a rule for the collection of bio-waste. By 2023 all EU states have to collect bio-waste separately or recycle it at the source (home composting) [3].

The bio-waste term refers to biodegradable garden and park waste, food and kitchen waste from households, restaurants, caterers, and retailers, and comparable waste from 
food processing plants [2]. Bio-waste accounts for about 30\% of the MSW stream and about $60 \%$ of bio-waste are made from food waste (FW) [4].

\subsection{Bio-waste processing methods}

Currently, in the EU, MSW (containing bio-waste from households) are mainly processed in the mechanical-biological treatment plants (MBT). In the MBT at the first step, waste is treated mechanically by screening to separate fractions streams. Undersize fraction constitutes mainly minerals and wet organic waste, while oversize fraction consists of plastics and other flammable materials. The screening process is not perfect, and therefore, part of plastics and other flammable materials go to the undersize fraction, while some organic waste stays in the oversize fraction. As a result, an undersize fraction is unfit for organic recycling, and plastics quality is lower in comparison to plastics collected separately at the source. After screening, the undersize fraction is processed by composting or anaerobic digestion to stabilize, where waste is converted into a low-grade compostlike output (CLO) which has to be landfilled [5,6].

On the other hand, when MSW are collected separately, the recycling rate of materials increases, and organics recycling of bio-waste is possible. Wastes streams collected separately have higher quality than mixed [5,6], and bio-waste can be converted by composting or anaerobic digestion to fertilizer. In both processes, microorganisms are used to break down organic matter. Compositing is the process under controlled conditions in the presence of oxygen, at an appropriate temperature and humidity of $\sim 60 \%$. Depending on composting technology, it may be done in pits, by piling and heaping [7], or in closed reactors with forced aeration also known as in-vessel systems [8]. During composting organic matter can heat itself to $70{ }^{\circ} \mathrm{C}$ at the thermophilic phase ensuring the destruction of pathogens [7]. The process also leads to a decrease in the mass and volume as a result of water evaporation and organic matter decomposition. Besides composting advantages like low-cost technology and easy process control, several drawbacks exist. The process requires external energy for heaps turning and/or aeration, and when out of a vessel system technology is used, gaseous and liquid emissions occur. Processing of green waste results in $\mathrm{CO}, \mathrm{CO}_{2}, \mathrm{CH}_{4}, \mathrm{H}_{2}, \mathrm{NH}_{3}, \mathrm{~N}_{2} \mathrm{O}, \mathrm{CH}_{4}$, and volatile organic compounds (VOCs) emissions which can't be avoided [9]. Therefore, if composting does not follow in closed reactors, a better option for biowaste processing is anaerobic digestion (AD).

Methane fermentation is a decomposition of organic matter under an oxygen-free atmosphere by anaerobic microorganisms at $37^{\circ} \mathrm{C}$ or $55^{\circ} \mathrm{C}$. The main process product is flammable biogas consisting of $\mathrm{CO}_{2}$ and $\mathrm{CH}_{4}$ about 1:1, and digestate residues that can be used as fertilizer or solid fuel as well. Similarly, to composting, a lot of different technologies exist. For an organic fraction of MSW best suited are (i) solid-state anaerobic digestion, (ii) continuous digestion with thermophilic conditions, and (iii) plug flow and continuous stirring tank rectors [6]. Though investment costs are much higher for anaerobic processes in comparison to aerobic ones, surplus energy production, comparable quality fertilizer, and almost zero emissions are plays in favor of AD [10]. Therefore, biogas plants will gradually replace composting ones.

\subsection{Problems with AD of bio-waste}

Due to a variable of bio-waste composition, conducting the AD process entails certain difficulties. To maintain biogas production at a stable level, many monitoring parameters need to be taken into count (total solids, volatile solids, $\mathrm{pH}$ value, ammonium nitrogen, volatile fatty acids (VFA), redox potential, alkalinity ratio, organic loading rate (OLR), hydraulic retention time (HRT) and the others). As a result trained workers with laboratory equipment are needed [11]. Lack of concise process control and optimization of bio-waste composition leads to harmful intermediate compounds production and process instability. It is due to organic waste nature. Most FW has acidic $\mathrm{pH}$ which consumes digested feedstock alkalinity and is quickly decomposed during the hydrolysis phase. Quickly decomposition with a combination of high protein and lipids content lead to rapid generation and accumulation of ammonia $\left(\mathrm{NH}_{3}\right)$, and VFAs over inhibitory levels [12]. Though high VFA concentration does not have to inhibit the process since VFAs are essential 
nutrients for bacteria growth, $\mathrm{pH}$ value needs to be kept at an optimal level to balance the inhibitory effects of VFAs and $\mathrm{NH}_{3}$ [13]. As a result of difficulties, AD of bio-waste (especially FW) is often performed at a low OLR of 2-3 gCoD $x(\mathrm{~L} \times \mathrm{d})^{-1}$ [12]. For that reason, different substances improving process stability and performance are added [13]. One of such substances getting attention recently is biochar.

Biochar is considered as the material improving the methane fermentation process [14]. Biochar can absorb compounds such as $\mathrm{H}_{2} \mathrm{~S}$ and $\mathrm{CO}_{2}$, it also has the potential to mitigate the inhibition of ammonia and acids. It creates also an optimal environment for the growth of microorganisms, which results in faster colony development and higher biogas yield. The effect of biochar addition (positive or negative) depends on the specific situation like reactor type (batch, continuous) substrate type, type of fermentation, type of the biochar, and others [14].

The biochar is produced from organic materials during thermal processing at temperatures above $300{ }^{\circ} \mathrm{C}$ in a free oxygen atmosphere. Depending on conditions, the process is called torrefaction $\left(200-320^{\circ} \mathrm{C}\right)$, pyrolysis $\left(>300^{\circ} \mathrm{C}\right)[15]$, or hydrothermal carbonization (180-320 ${ }^{\circ} \mathrm{C}$ ) [16]. Besides temperature, other parameters specify these processes, inter alia residence time, pressure, and initial moisture. Torrefaction and pyrolysis are performed at atmospheric pressure for pre-dried materials, while hydrothermal carbonization is performed at overpressure for wet materials. Each process has pros and cons and is used for different materials and purposes. The amount, quality (desired properties) of carbonaceous material obtained from thermal processing depends on feedstock type and process conditions. In general, the higher the process temperature, the more energy-consuming is thermal processing and the lower amount of biochar is produced in favor of the yield of other products (liquid and gases) [15-17]. Therefore, low-temperature biochars produced with lower energy demand than under high-temperature pyrolysis may be considered as a sustainable source of structural additive for FW AD. The scientific question on its influence on AD performance may be derived.

\subsection{Study Aim}

All the advantages of the AD process improvement by biochar addition have not been fully explored, because biochar can be produced from various substrates, under different conditions and various substrates can be processed by AD. Additionally, the application of biochar produced from the same materials as being processed under AD has been studied rarely [18]. In this work, five low-temperature biochars that potentially could be made using residual heat from biogas combined heat and power unit $\left(300-400{ }^{\circ} \mathrm{C}\right)$ were produced and used to enhance AD of FW. Moreover, biochars were produced from the substrate (here food waste) under torrefaction, low-temperature pyrolysis, and hydrothermal carbonization conditions.

\section{Materials and Methods}

\subsection{Materials}

\subsubsection{Inoculum preparation}

As inoculum for biochemical methane potential tests, digestate from the $1 \mathrm{MW}$ el commercial agricultural biogas plant (Bio-Wat Sp. Z o. o., Świdnica, Poland) was used. The digestate was collected to plastic canisters and was taken to the laboratory where was stored at room temperature for $\sim 24 \mathrm{~h}$. On the next day, the digestate was filtered through gauze to separate liquid from solid particles: unprocessed substrate, plastics, etc. Then, the liquid digestate was stored in the climate chamber (Pollab, model 140/40, Wilkowice, Poland) at $4{ }^{\circ} \mathrm{C}$ before the biochemical methane potential test. The liquid digestate was characterized by $94.7 \%$ of moisture content, $5.3 \%$ of total solids, $59.3 \%$ of volatile solids, and $40.7 \%$ of ash content. The digestate $\mathrm{pH}$ was 7.86 , and EC was $68.8 \mu \mathrm{S} \mathrm{x} \mathrm{cm}-1$.

\subsubsection{Food waste preparation}

Food waste mixture for biochemical methane potential tests was prepared from food purchased in the grocery store. The mixture consists of $3.67 \%$ of orange, $8.67 \%$ of banana, 
$7.33 \%$ of apple, $1.33 \%$ of lemon, $24.33 \%$ of potatoes, $4.67 \%$ of onion, $3.33 \%$ of salad, $3.33 \%$ of cabbage, $2.33 \%$ of tomatoes, $6 \%$ of rice, $6 \%$ of pasta, $3 \%$ of bread, $3 \%$ of meat, $12 \%$ of fish meat, and $11 \%$ of cheese by fresh mass. The fresh food waste mixture had $64.2 \%$ of moisture content (MC), while volatile solids (VS) constituted $95.8 \%$ of dry mass. The ash content (AC) of the mixture was $4.2 \%$. The FW composition was based on the work of Valta et al. [19]. The properties of moisture content, total solids (TS), volatile solids (organic matter content), and ash content, of used food materials, and mixture composition per fresh, dry, and volatile solids percentage share bases are presented in Table 1.

Table 1. Food waste properties and its share in food waste mixture

\begin{tabular}{|c|c|c|c|c|c|c|c|}
\hline \multirow{2}{*}{ Material, - } & \multicolumn{4}{|c|}{ Basic properties } & \multicolumn{3}{|c|}{ Share in mixture } \\
\hline & $\mathrm{MC}, \%^{*}$ & TS, \%* & VS, $\%$ ** & $\mathrm{AC}, \% * *$ & By fresh mass, $\%$ & by dry mass, $\%$ & by VS, \% \\
\hline Mixture & 64.2 & 35.8 & 95.8 & 4.2 & - & - & - \\
\hline Orange & 86.2 & 13.8 & 95.3 & 4.7 & 3.67 & 1.42 & 1.43 \\
\hline Banana & 81.4 & 18.6 & 87.8 & 12.2 & 8.67 & 4.51 & 4.19 \\
\hline Apple & 87.4 & 12.6 & 95.4 & 4.6 & 7.33 & 2.58 & 2.60 \\
\hline Lemon & 85.4 & 14.6 & 93.5 & 6.5 & 1.33 & 0.55 & 0.54 \\
\hline Potatoes & 61.6 & 38.4 & 93.1 & 6.9 & 24.33 & 26.11 & 25.73 \\
\hline Onion & 89.2 & 10.8 & 93.4 & 6.6 & 4.67 & 1.41 & 1.40 \\
\hline Salad & 94.9 & 5.1 & 85.7 & 14.3 & 3.33 & 0.48 & 0.43 \\
\hline Cabbage & 92.2 & 7.8 & 91.6 & 8.4 & 3.33 & 0.72 & 0.70 \\
\hline Tomatoes & 95.1 & 4.9 & 82.1 & 17.9 & 2.33 & 0.32 & 0.32 \\
\hline Rice & 13.2 & 86.8 & 99.4 & 0.6 & 6.00 & 14.55 & 15.31 \\
\hline Pasta & 11.6 & 88.4 & 95.5 & 4.5 & 6.00 & 14.84 & 15.00 \\
\hline Bread & 22.5 & 77.5 & 95.2 & 4.8 & 3.00 & 6.50 & 6.54 \\
\hline Meat & 69.8 & 30.2 & 96.0 & 4.0 & 3.00 & 2.53 & 2.57 \\
\hline Fish meat & 81.7 & 18.3 & 95.5 & 4.5 & 12.00 & 6.12 & 6.19 \\
\hline Cheese & 43.5 & 56.5 & 92.8 & 7.2 & 11.00 & 17.37 & 17.06 \\
\hline & & & & $\begin{array}{r}* \text { as receiv } \\
{ }^{* *} \text { as dry }\end{array}$ & $\begin{array}{l}\text { base } \\
\text { ase }\end{array}$ & & \\
\hline
\end{tabular}

FW components were dried in the laboratory dryer (WAMED, model KBC-65W, Warsaw, Poland) at $105{ }^{\circ} \mathrm{C}$ and shredded. Drying time differed depending on the food type. Then, dry food was ground through a $1 \mathrm{~mm}$ screen using a laboratory knife mill (Testchem, model LMN-100, Pszów, Poland). Ground FW samples were stored in plastic string bags, at room temperature. The mixture for AD was prepared from ground dry food materials according to data presented in Table 1. To ensure mixture homogeneity, one portion of $1 \mathrm{~kg}$ was prepared before the biochemical methane potential test. And all tests were done using this mixture.

\subsubsection{Low-temperature biochars preparation and analyses}

The low-temperature biochars, low-temperature and low-pressure biochars, and low-pressure hydro-char were produced using a prototype batch laboratory reactor (WUELS, RBMT2020-1.1, Wrocław, Poland). The reactor description is available elsewhere [20]. The biochars were produced from a dry FW mixture at $300{ }^{\circ} \mathrm{C}$ and $400{ }^{\circ} \mathrm{C}$ in $60 \mathrm{~min}$, at atmospheric pressure, and overpressure of 15 bars. Because the pressure vs temperature parameter is dependent, the residence time for biochar production (60 $\mathrm{min}$ ) was counted since setpoint temperature was obtained. When the pressure in the reactor increased over 15 bars, it was released manually up to 14 bars. An exemplary biochar production parameters diagram is presented in Figure A1. The outer reactor wall 
temperature was around $150{ }^{\circ} \mathrm{C}$ higher than the setpoint temperature (inside the reactor). For low-pressure hydrothermal carbonization (15 bars), a dry FW mixture was mixed with water to obtain $64.2 \%$ moisture content (to simulate the initial moisture of FW). The setpoint temperature for hydrothermal carbonization was $280^{\circ} \mathrm{C}$.

For each process, 5 samples for $50 \mathrm{~g}$ at once $(250 \mathrm{~g})$ were used. The samples were placed in the reactor in an aluminum tray covered with aluminum foil to prevent oxidation at the initial stage. All pressure was released after 60 min since the setpoint temperature was reached, and the reactor was left to cool down. Then samples were removed from the reactor after reactor temperature reach room temperature. The difference between the initial and end mass of solids was used to calculate the mass yield of the biochar production following equation 1.

$$
M Y=\frac{m_{b}}{m_{r}} \times 100
$$

Where:

$M Y$ - mass yield, \%;

$m_{b}$ - mass of biochar after the process, $\mathrm{g}$,

$m_{r}$ - mass of material before process, $\mathrm{g}$.

Produced biochars were analyzed for specific surface area (BET), total pore volume $<50 \mathrm{~nm}(\mathrm{Vt})$, and average pore size $<50 \mathrm{~nm}(\mathrm{~L})$ by adsorption analyzer (Micromeritics, ASAP 2020, Norcross, USA).

\subsection{Methods}

\subsubsection{Biochemical methane potential test}

Biochemical methane potential (BMP) tests were performed using an automatic methane potential test system (BPC Instruments AB, AMPTS ${ }^{\circledR}$ II, Lund, Sweden). The system consists of 15 reactors $(500 \mathrm{ml})$ with agitation, gas volume meters as well as a built-in data acquisition system. Due to the presence of $\mathrm{CO}_{2}$ absorption units filled with $\mathrm{NaOH}$ solution, only $\mathrm{CH}_{4}$ volume was measured. Biomethane potential test took 21 days and was performed in two replications. Each replication consists of two reactors filled with digestate; two reactors filled with digestate and FW, and two reactors filled with digestate, FW, and biochar according to the matrix presented in Table 2. For each reactor, $300 \mathrm{~g}$ of liquid digestate was used. For each reactor (excluded two first) $3.96 \mathrm{~g}$ of dry FW mixture was added, and for reactors with BC, $0.1982 \mathrm{~g}$ of dry biochar was added. As a result, the substrate to inoculum ratio (SIR) was 0.4 by VS (or 0.25 by TS), the total solids in the reactors were $6.53-6.59 \%$ and biochar share in FW was 5\% (by total solids). At the beginning and end of the test, ph and electrical conductivity (EC) was measured using a ph/EC meter (Elmetron, CPC-411, Zabrze, Poland).

The SIR of 0.4 was chosen due to works of [21,22] which show that for FW, the optimal SIR varies from 0.33 to 0.5 , while $5 \%$ BC share in food waste by TS was chosen due to our previous work [18]. 5\% share of biochar addition considered in current study is equal to biochar addition of $0.05 \mathrm{gBC}_{\mathrm{B}} \times$ g $_{\text {TSsubstrate }}{ }^{-1}$, or $0.65 \mathrm{gBC}_{\mathrm{B}} \mathrm{L}^{-1}$.

Table 2. Anaerobic digestion experiment matrix, D - digestate, $\mathrm{FW}$ - food waste, $\mathrm{BC}$ - - specific biochar derived under following conditions temperature, ${ }^{\circ} \mathrm{C} /$ residence time, min./pressure, bar

\begin{tabular}{cccc}
\hline Sample & Digestate & Food waste mixture & Biochar \\
\hline D & + & - & - \\
D & + & - & - \\
D+FW & + & + & - \\
D+FW & + & + & - \\
D+FW+BC_300/60/0 & + & + & + \\
D+FW+BC_300/60/0 & + & + & + \\
D+FW+BC_300/60/15 & + & + & + \\
D+FW+BC_300/60/15 & + & + & + \\
D+FW+BC_400/60/0 & + & + \\
D+FW+BC_400/60/0 & + & + \\
\hline
\end{tabular}




\begin{tabular}{llll} 
D+FW+BC_400/60/15 & + & + & + \\
D+FW+BC_400/60/15 & + & + & + \\
D+FW+BC_HTC280 & + & + & + \\
D+FW+BC_HTC280 & + & + & + \\
\hline
\end{tabular}

FW - food waste mixture

BC_300/60/0 - biochar produced at $300{ }^{\circ} \mathrm{C}$ in $60 \mathrm{~min}$ and atmospheric pressure,

BC_300/60/15 - biochar produced at $300^{\circ} \mathrm{C}$ in $60 \mathrm{~min}$ and overpressure pressure of 15 bars

BC_400/60/0 - biochar produced at $300{ }^{\circ} \mathrm{C}$ in $60 \mathrm{~min}$ and atmospheric pressure,

BC_400/60/150 - biochar produced at $300^{\circ} \mathrm{C}$ in $60 \mathrm{~min}$ and overpressure pressure of 15 bars

HTC280 - biochar/hydrochar produced in hydrothermal carbonization process at $280^{\circ} \mathrm{C}$ in 60 min at a pressure up

to 15 bars

\subsubsection{Materials and process residues analysis}

All material used in the study was subjected to moisture content, total solids, volatile solids, and ash content determination. The moisture content and total solids were determined using the laboratory dryer (WAMED, model KBC-65W, Warsaw, Poland), according to PN-EN 14346:2011 standard [23], while volatile solids and ash content were determined using the muffle furnace (SNOL, 8.1/1100, Utena, Lithuania) according to PN-EN 15169:2011 standard [24].

FW mixture was additionally subjected to ultimate analysis for determination of the elemental composition $(\mathrm{C}, \mathrm{H}, \mathrm{N}, \mathrm{S}, \mathrm{O})$. The ultimate analysis was performed using a CHNS analyzer (Perkin Elmer, $2400 \mathrm{CHNS} / \mathrm{O}$ Series II, Waltham, United States) according to 12902:2007 [25]. The oxygen content was calculated by difference according to equation 2

$$
O=100-C-H-N-S-A C
$$

where:

$O$ - oxygen $\%$ share in dry mass, $\%$,

C - carbon \% share in dry mass, \%,

$\mathrm{H}$ - hydrohen \% share in dry mass, \%,

$S-$ sulfur \% share in dry mass, \%,

$A C$ - ash \% share in dry mass, $\%$.

The elemental composition was used for the calculation of theoretical biogas composition, and the theoretical biochemical methane potential (TBMP). Calculations were done according to Boyle modification of Buswell and Mueller stoichiometric formula, equation 3 [26].

$\mathrm{C}_{a} \mathrm{H}_{b} \mathrm{O}_{c} \mathrm{~N}_{d} \mathrm{~S}_{e}+\left(a-\frac{b}{4}-\frac{c}{2}+\frac{3 d}{4}+\frac{e}{2}\right) \mathrm{H}_{2} \mathrm{O} \rightarrow\left(\frac{a}{2}+\frac{b}{8}-\frac{c}{4}-\frac{3 d}{8}-\frac{e}{4}\right) \mathrm{CH}_{4}+\left(\frac{a}{2}-\frac{b}{8}+\frac{c}{4}+\frac{3 d}{8}+\frac{e}{4}\right) \mathrm{CO}_{2}+d \mathrm{NH}_{3}+e \mathrm{H}_{2} \mathrm{~S}$

where:

$C_{a} H_{b} O_{c} N_{d} S_{e}$ - elemental composition of the substrate, $\mathrm{C}$ - carbon, $\mathrm{H}$ - hydrogen, $\mathrm{O}$ - oxygen, $\mathrm{N}$ - nitrogen, $\mathrm{S}$ - sulphury, and $a, b, c, d$, e stands for molar \% share of specific elements of the volatile solids of biomass [27].

$\mathrm{H}_{2} \mathrm{O}$ - water needed for substrate decomposition, mol,

$\mathrm{CH}_{4}$ - methane, mol,

$\mathrm{CO}_{2}$ - carbon dioxide, mol,

$\mathrm{NH}_{3}$ - ammonia, mol,

$\mathrm{H}_{2} \mathrm{~S}$ - hydrogen sulfide, mol.

The mols of biogas products $\left(\mathrm{CH}_{4}, \mathrm{CO}_{2}, \mathrm{NH}_{3}, \mathrm{H}_{2} \mathrm{~S}\right)$ were recalculated for volume in standard conditions ( $p=1013.25 \mathrm{hPa}, T=273.15 \mathrm{~K}$ ) by multiplication obtained mols by 22.415 obeying Avogadro law. Knowing the elemental composition of substrates and the molar mass of each element, the mass of 1 mol of the substrate was calculated. Next, the volume of each gas component was divided by the mass of 1 mole of substrate used for 
its production, providing a result in $\mathrm{dm}^{3}$ per gram of dry substrate. Then, knowing the volatile solids of a substrate, results were recalculated to $\mathrm{dm}^{3}$ of gas per gram of volatile solids of a substrate.

Additionally, the FW biodegradability was calculated using data of cumulative methane production and theoretical maximum methane production following equation (4) [28].

where:

$$
B D=\frac{E B M P}{T B M P} \times 100
$$

$B D$ - biodegradability of FW obtained in the methane fermentation process, $\%$,

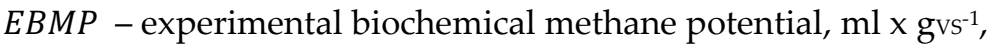

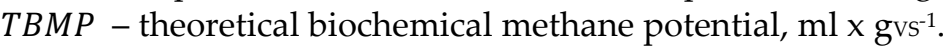

\subsubsection{Methane production kinetics}

The results of the BMP test were subjected to kinetics determination. The first-order equation (equation 5) was used to provide information about the rate of methane production and the estimated value of maximum methane production potential with the application of Statistica 13.0 software (TIBCO Software Inc., Palo Alto, CA, USA). Afterward, the methane production rate was calculated (equation 6) [18].

$$
\begin{gathered}
B M P=E B M P_{e} \times\left(1-e^{(-k x t)}\right) \\
r=k \times E B M P_{e}
\end{gathered}
$$

where:

$B M P$ - the cumulative methane production obtained from a substrate after time $\mathrm{t}, \mathrm{mlcH}_{4} \mathrm{x}$ $\mathrm{gvs}^{-1}$,

$E B M P_{e}$ - the estimated value of experimental maximum methane production obtain from a substrate, mlcH4 $\mathrm{Xgvs}^{-1}$,

$k$ - constant reaction rate, $\mathrm{d}^{-1}$,

$t$ - process time, $\mathrm{d}$,

$r$ - methane production rate, $\operatorname{ml}_{\mathrm{CH} 4} \times(\mathrm{gvs} \times \mathrm{d})^{-1}$.

\subsubsection{Statistical analysis of biochar effect}

To check if biochar addition had a statistically significant effect (positive or negative) on the methane fermentation, the one-way analysis of variance with post hoc Tukey tests was performed at the level of $\alpha=0.05$, with the application of Statistica 13.0 software (TIBCO Software Inc., Palo Alto, CA, USA).

\section{Results and discussion}

\subsection{Substrate and Biochar Properties}

The liquid digestate used for BMP had $94.7 \%$ of MC, $5.3 \%$ of TS, $59.3 \%$ of VS, and $40.7 \%$ of AC, while FW mixture (substrate) used for BMP tests, had $5.6 \%$ of MC, $94.4 \%$ of TS, 95.8 of VS, and $4.2 \%$ of AC (Table 1). The elemental analysis showed that FW mixture was characterized by $44-47.8 \%, 5.7-6.2 \%, 39.9-44.4 \%, 1.45-1.58 \%, 0.24-0.26 \%$ of $\mathrm{C}, \mathrm{H}, \mathrm{O}, \mathrm{N}$, $\mathrm{S}$, respectively (by dry mass base). Besides, the FW mixture was characterized by a $\mathrm{pH}$ of 5.62 and $\mathrm{EC}$ of $3.6 \mathrm{mS} \mathrm{x} \mathrm{cm}^{-1}$.

The 5 types of biochars were used depending on the production conditions as follows temperature/time/pressure, however, the HTC280 means hydrothermal carbonization process at $280{ }^{\circ} \mathrm{C}$ in $60 \mathrm{~min}$. The biochars were characterized by MY ranging from $34.3 \%$ to $72.6 \%$ for $400 / 60 / 15$ and HTC280, respectively (Table 3). The highest MY was noted in the case of HTC and the 300/60/15 process (Table 3). As result, for biochars with high MY, less substrate and energy is needed for their production in comparison to biochars with low MY. Nevertheless, in such a scenario the substrate is less converted and biochar may do not have desired properties [29]. Produced biochars had a relatively low volatile solids content in comparison to FW used for biochar production. On the other hand, biochars had a much higher ash content than the FW mixture. The ash content in biochar varied from $10.4 \%$ to $39.1 \%$, while the FW mixture had only $4.2 \%$ of ash. The produced biochar was also analyzed for specific surfaces area (SSA) according to BET theory, total pore 
volume $<50 \mathrm{~nm}\left(\mathrm{~V}_{\mathrm{t}}\right)$, and average pore size $<50 \mathrm{~nm}(\mathrm{~L})$. Moreover, produced biochars had a value of SSA ranging from 0.26 to $0.64 \mathrm{~g} \mathrm{x} \mathrm{m}^{-2}$, and pore size ranging from 5.2 to $7.1 \mathrm{~nm}$ (Table 3). The total pore volume ranged from $3.3 \times 10^{-4} \mathrm{~cm}^{3} \times \mathrm{g} \mathrm{g}^{-1}$ to $8.2 \times 10^{-4} \mathrm{~cm}^{3} \mathrm{x} \mathrm{g}^{-1}$, excluding $400 / 60 / 15$ biochar that had $\mathrm{V}_{t}$ of $11.3 \times 10^{-4} \mathrm{~cm}^{3} \mathrm{x} \mathrm{g}^{-1}$ (Table 3). The pyrolysis result in biochars' $\mathrm{pH}$ increase from 5.62 to $8.61-10.75$ except HTC280 for which $\mathrm{pH}$ decreased to 5.59. Except for biochar produced at $300^{\circ} \mathrm{C}$, all biochars had higher EC in comparison to the FW (Table 3).

Table 3. Low-temperature biochar properties

\begin{tabular}{|c|c|c|c|c|c|c|c|c|c|c|}
\hline Material, - & $\begin{array}{c}\text { MY, } \\
\%\end{array}$ & $\mathrm{MC}, \%$ * & TS, \%* & VS, $\%$ ** & $\mathrm{AC}, \%$ \%* & $\begin{array}{c}\text { SSA, } \\
\text { m }^{2} \mathbf{x} \\
\mathbf{g}^{-1}\end{array}$ & $V_{t}, \mathrm{~cm}^{3} \times g^{-1}$ & $\begin{array}{c}\mathrm{L}, \\
\mathrm{nm}\end{array}$ & $\mathrm{pH}^{* * *}$ & $\begin{array}{c}\mathrm{EC}, \\
\mathrm{mS} \\
\mathrm{x} \\
\mathrm{cm}^{-} \\
1^{* * * *}\end{array}$ \\
\hline $300 / 60 / 0$ & 42.6 & 4.5 & 95.5 & 79.5 & 20.5 & 0.62 & $8.2 \times 10^{-4}$ & 5.2 & 8.61 & 3.04 \\
\hline $300 / 60 / 15$ & 45.9 & 3.3 & 96.7 & 89.6 & 10.4 & 0.26 & $3.3 \times 10^{-4}$ & 5.0 & 8.04 & 3.57 \\
\hline $400 / 60 / 0$ & 37.4 & 4.4 & 95.6 & 77.3 & 22.7 & 0.61 & $7.6 \times 10^{-4}$ & 5.0 & 10.19 & 4.53 \\
\hline $400 / 60 / 15$ & 34.3 & 4.0 & 96.0 & 60.9 & 39.1 & 0.64 & $11.3 \times 10^{-4}$ & 7.1 & 10.75 & 7.69 \\
\hline HTC280 & 72.6 & 5.0 & 95.0 & 88.1 & 11.9 & 0.38 & $5.6 \times 10^{-4}$ & 5.9 & 5.59 & 4.71 \\
\hline \multicolumn{11}{|c|}{${ }^{*}$ air-dry base } \\
\hline
\end{tabular}

The pore volume, pore size, specific surface area, $\mathrm{pH}$, elemental composition, surface functional groups, electrical conductivity (EC), and cation exchange capacity (CEC) are considered as key biochar physicochemical properties which affect the AD and biogas production [30]. Porosity is considered a key factor to recognize the plausible relations with microbes in AD. The porosity is characterized in terms of the average diameter [31] and is described by three main pore types, micropores $(<2 \mathrm{~nm})$, mesopores $(2-50 \mathrm{~nm})$, and macropores $(>50 \mathrm{~nm})$. For activated carbon, a specific surface area of micropores may constitute up to $95 \%$ of the total SSA of activated carbon. As result, micropores decide about the adsorption capacity. On the other hand, mesopores significantly contribute to the adsorption of larger particles, such as dye or humic acids [32]. Generally, pores with a radius over $25 \mathrm{~nm}$ are considered transport pores, while pores smaller than $25 \mathrm{~nm}$ are considered adsorbing ones [33]. Besides absorption, pores provide microorganism habitat for proliferating, since the typical size of bacteria is $0.3 \mu \mathrm{m}$ to $13 \mu \mathrm{m}$. The higher SSA, the more effective biochar is in the interaction with the surrounding species [31]. The SSA of biochar varied significantly depending on substrate and process conditions. The SSA in activated carbons varies from 419 to $3102 \mathrm{~m}^{2} \mathrm{x} \mathrm{g}^{-1}$ [34], while for low-temperatures and not activated biochar $\left(350-500{ }^{\circ} \mathrm{C}\right)$, it varies from 0.36 to $5.31 \mathrm{~g} \mathrm{x} \mathrm{m}^{-2}$. Moreover, pore volume and average pore size in such biochars vary from $10 \times 10^{-4}$ to $8010^{-4} \mathrm{~cm}^{3} \times \mathrm{g} \mathrm{g}^{-1}$, and 2.39 to $14.60 \mathrm{~nm}$, respectively [35]. It means that biochars produced in the current study do not differ significantly in comparison with other biochars produced at similar temperatures, but have incomparably smaller SSA in comparison to activated carbon.

Since electrically conductive materials (i.e. mineral particles, carbon materials) added to $\mathrm{AD}$ show to reduce lag phase and increase methane production rates, electrically conductive materials found more attention. Conductive materials (i.e. biochar, graphite, activated carbon) added to $\mathrm{AD}$ can promote direct interspecies electron transfer (DIET) between syntrophic partners [36]. The DIET is an alternative to interspecies $\mathrm{H} 2 /$ formate transfer for syntrophic electron exchange between microbial species. In $\mathrm{AD}$, some methanogens can receive electrons from other microorganisms by molecular electric connections or by conductive materials [37]. For that reason, materials with good electrical conductivity properties are assumed to help enhance methane fermentation. The biochar 
electrical conductivity can be measured in solid-state [38], as powder [39], or in water solution, like soil EC is measured [40]. The EC varies depending on the method, and therefore cautions is needed when data is compared between studies. Nevertheless, results from the same method show that an increase in pyrolysis temperature increases EC value. And it is due to higher carbonization and an increase in ash content [39]. Biochar EC values may vary from $0.04 \mathrm{mS} \mathrm{x} \mathrm{cm}^{-1}$ to $54.2 \mathrm{mS} \mathrm{x} \mathrm{cm}^{-1}$, and besides pyrolysis temperature, the feedstock affects EC as well [40]. These show that biochar produced in this study had relatively low EC (3.04-7.69 mS x cm-1$)$ in comparison to biochars found in the literature.

The $\mathrm{pH}$ is an important factor affecting the BMP test results and will be described in more detail later. Here is worth noting that all biochars except HTC280 were alkaline, and their $\mathrm{pH}$ increased with process temperature, while HTC280 become more acid. Also, worth is noting that $\mathrm{pH}$ did not change when pressure was applied, while EC increased, 3.04 vs $3.57 \mathrm{mS} \mathrm{x} \mathrm{cm}^{-1}$ for biochars made at $300{ }^{\circ} \mathrm{C}$, and 4.53 vs $7.69 \mathrm{mS} \mathrm{x} \mathrm{cm}^{-1}$ for biochars made at $400{ }^{\circ} \mathrm{C}$. This suggests that pressure may potentially be a parameter that can be used to modify EC. This finding should be further investigated.

\subsection{Biochemical Methane Potential - theoretical and experimental}

The effect of low-temperature biochar addition on the cumulative biomethane production process during 21 days was investigated (Figure 1). The result shows that the highest methane production was obtained for biochar from hydrothermal carbonization (HTC280) and biochar produced at 400/60/0. The control reactors obtained $347.9 \mathrm{mlcH}_{4} \mathrm{X}$ gvs $^{-1}$, while reactors with biochars 400/60/0 and HTC280 had $360.1 \mathrm{mlcH}_{4} \mathrm{X} \mathrm{gvs}^{-1}$ and 365.2 mlcн4 $\mathrm{x} \mathrm{gvs}^{-1}$, respectively (Figure 1). The lowest value of BMP was obtained for reactors where biochar 400/60/15 was added (331.7 $\left.\mathrm{mlcH}_{4} \times \mathrm{gvs}^{-1}\right)$.

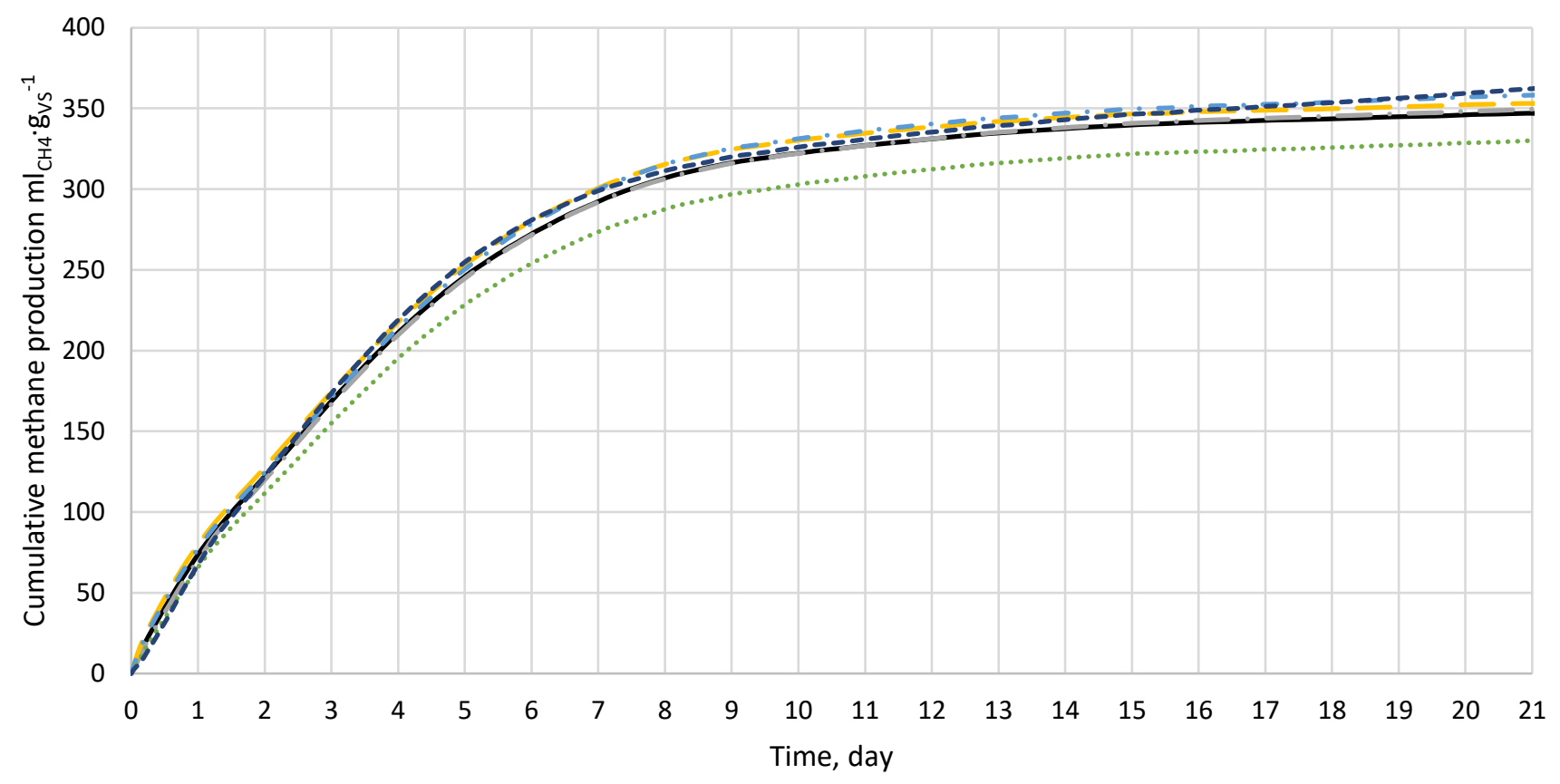

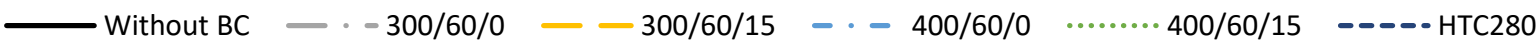

Figure 1. Biomethane production from food waste $(\mathrm{n}=4)$ The results show $\mathrm{CH}_{4}$ production in $\mathrm{ml}$ per gram of food waste volatile solids, the $\mathrm{CH}_{4}$ produced by inoculum (digestate) was subtracted.

The theoretical biochemical methane potential of the food waste mixture was 460 mlcн4 $\mathrm{xgvs}^{-1}$ (equation 3). Besides, theoretical calculations showed that for complete substrate conversion into biogas, $437 \mathrm{mlco} \mathrm{x} \mathrm{gvs}^{-1}, 25 \mathrm{mlNH}_{3} \mathrm{x} \mathrm{gvs}^{-1}$, and $2 \mathrm{ml}_{2} \mathrm{x} \times \mathrm{gvs}^{-1}$ will be produced. The experimental BMP test for control samples after 21 days obtained 347.9 mlcH 4 gvs $^{-1}$ (Figure 1) reaching $75.5 \%$ substrate biodegradation. 
Experimentally BMP values obtained in this study are lower than the BMP value for source-separated domestic FW collected in the EU, for which BMP range from 420 to 470 mlch4 $\mathrm{x} \mathrm{gvs}^{-1}$ [41]. Nevertheless, the theoretical potential is in this range, and most reactors reached $\mathrm{BD}$ over $75 \%$, which suggests that $\mathrm{BMP}$ was done properly, especially since the processing time was only 21 days.

Table 4. The biochar addition effect on the process residues and methane production, after 21 days

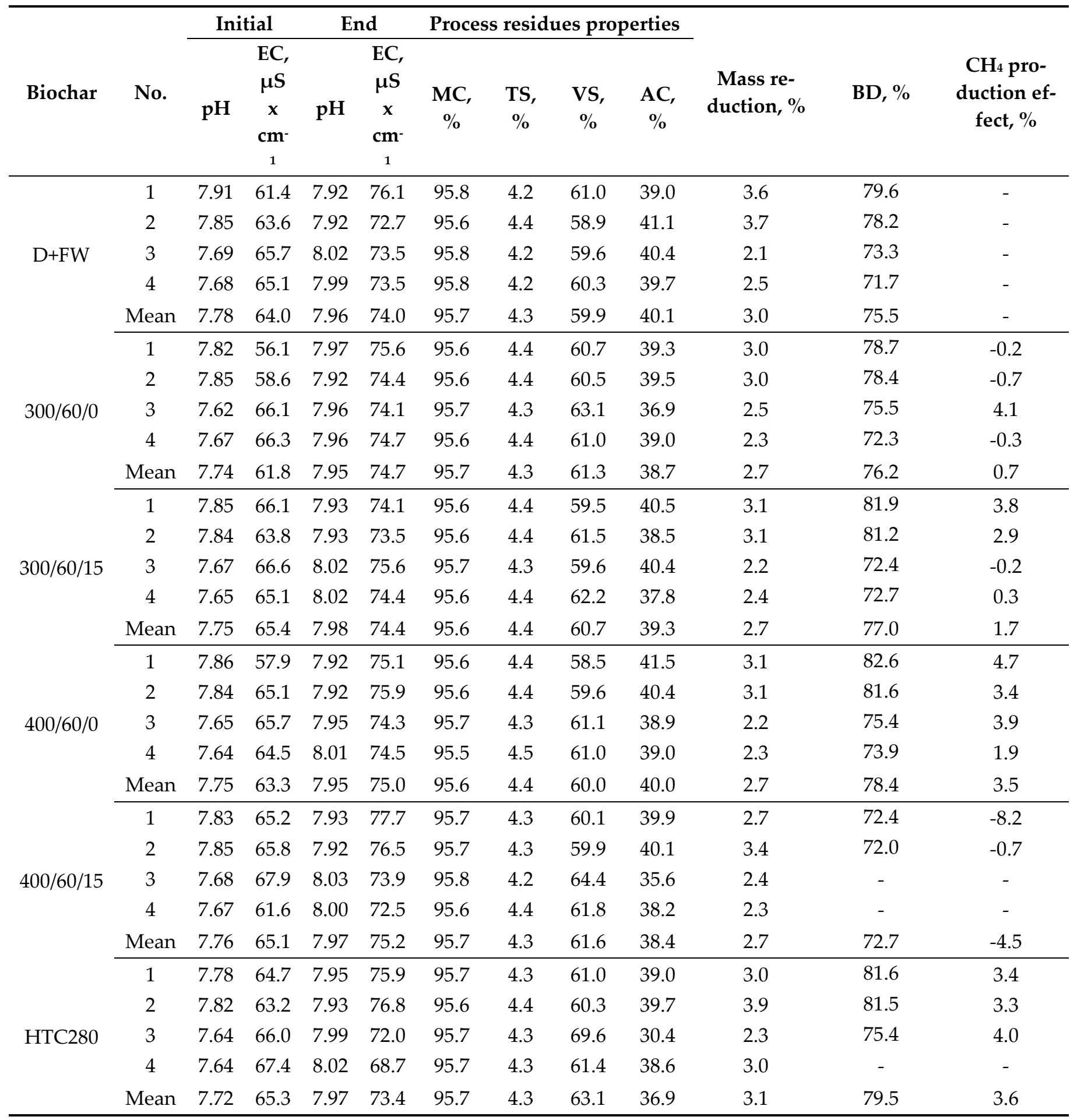

The $\mathrm{CH}_{4}$ production effect shows a difference between the value obtained from the control (D+FW) and the reactor with biochar (Table 4). When the value is greater than 0 , biochar increased the methane production, while the value is lower than 0 , biochar decreased methane production in comparison to control. The biochar addition had a positive 
effect on methane production from FW. Only biochar 400/60/15 showed a decrease in methane production. For this biochar, all reactors produced less methane than control. For other biochars mean value from the repetitions was generally positive, more methane was produced than by control. Nevertheless, biochars produced at $300{ }^{\circ} \mathrm{C}$ led to a decrease in methane production in some repetitions. The highest methane production was obtained from reactors where 400/60/0 and HTC280 were added, 3.5\%, and 3.6\% respectively (Table $4)$.

The initial $\mathrm{pH}$ in all reactors with $\mathrm{FW}$ and biochar differed from 7.62 to 7.91 , while EC differed from 56.1 to $67.9 \mu \mathrm{S} \times \mathrm{cm}^{-1}$. After 21 days of the process, $\mathrm{pH}$ differed from 7.92 to 8.03 , and EC differed from 68.7 to $77.7 \mu \mathrm{S} \times \mathrm{cm}^{-1}$ (Table 4). For comparison, digestate alone had initial $\mathrm{pH}$ and $\mathrm{EC}$ of 7.86 , and $66.8 \mu \mathrm{S} \times \mathrm{cm}^{-1}$, respectively, while after 21 days

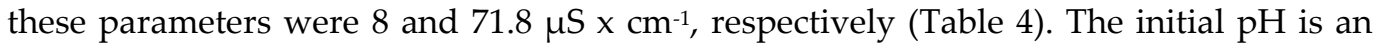
important parameter affecting methane yield in batch experiments, but no one value would show the correctness of the process [42]. The initial $\mathrm{pH}$ and then its changes during the process affect products yield. As optimal $\mathrm{pH}$ was reported value from 6.8 to 7.4 [43]. Anaerobic digestion is four stage process consisting of hydrolysis, acidogenesis, acetogenesis, and methanogenesis. The $\mathrm{pH}$ is crucial in each stage, and each of them required a different value. A positive correlation was found between the hydrolysis rate and $\mathrm{pH}$ [43]. The optimal $\mathrm{pH}$ for acidogenesis is 5.5-6.5 [44], while methanogenesis is effective when $\mathrm{pH}$ is around 6.5-8.2 (with optimum $\mathrm{pH}$ of 7.0) [45]. Even though methanogenesis is effective at 6.5, the methanogens growth rate is reduced significantly at $\mathrm{pH}$ lower than 6.6 [46]. Therefore, the best result of AD can be obtained by division process into two stages hydrolysis with acidogenesis, and acetogenesis with methanogenesis [43]. The $\mathrm{pH}$ also affects the decomposition of total solids, and volatile solids in the reactor, as well as volatile fatty acids composition [47,48]. Nevertheless, in this study biochar addition did not change significantly $\mathrm{pH}(\mathrm{p}<0.05)$, and as result, all reactors had similar conditions. Here is worth noting that for some reason, biochars with completely different $\mathrm{pH}, 10.19$ vs 5.59 for 400/60/0 and HTC280, respectively showed to give the best methane production enhancement. The reason for that may be some other biochar properties that were not considered in this study. Maybe these biochars enhanced buffer capacity in the highest way despite different $\mathrm{pH}$, and as result provided better conditions for microorganism growth.

The EC shows the number of dissolved salts in solutions and is proportional to the quantity of these salts. The solutions with higher salts concentration have a greater ability to conduct an electrical current [40]. In the methane fermentation process, this parameter alone is rather useless. Nevertheless, EC can be used in online monitoring of biogas plants for prediction in advance methane production up to 2 days [49], or alkalinity [50]. As mentioned previously, conductive materials can enhance methane production by DIET. Nevertheless, in this study, biochar addition did not change the electrical conductivity of the solution significantly ( $\mathrm{p}<0.05$ ), therefore is highly probable that DIET had no effect here.

Generally, biochar addition did not lead to significant $(\mathrm{p}<0.05)$ changes in $\mathrm{pH}$, and EC, obtained biodegradability, substrate mass reduction, and amount of produced $\mathrm{CH}_{4}$. But, even no statistically significant differences were found, results of biochar made at 400/60/0 and HTC280 showed to have always higher methane production than control, averagely by $3.5 \%$ (Table 4 ). At the first sight, it looks small, however, when the 1 MWe FW biogas plant working for $8000 \mathrm{~h}$ per year is considered, after the addition of BC the additional $280 \mathrm{MWh}$ of electricity may be produced. It is worth to be noted, that usually biogas plants have problems with the utilization of heat, which in this case may be used for BC production.

\subsection{Biomethane Production Kinetics}

The mean kinetic parameters evaluated by the model for control (D+FW) was $k=$ $0.240 \mathrm{~d}^{-1}, E B M P_{e}=351.4 \mathrm{mlcH}_{4} \times \mathrm{gvs}^{-1}$ and $r=84.43 \mathrm{mlcH}_{4} \times(\text { gvs } \mathrm{x} \mathrm{d})^{-1}$ (Table 5). All determined kinetics had a high determination coefficient $(R>0.99)$ (Table 5$)$ what suggests the used model fits the experimental data well. In general first-order model is used for fast 
and abruptly stopping degradation substrates [51]. And there was no need to use more sophisticated models like the modified Gompertz equation (good fitting when a lag phase is present), the mondo model (good fitting when gas production slowly declining at the end of the process), or two first-order equations (good fitting when two separate degradation profiles occur) [51] since here none of such situation took place and biodegradation of over $75 \%$ was obtained in 21 days (Table 4 ).

The biochar addition changed slightly the values of kinetic parameters, but these changes were not statistically significant $(\mathrm{p}<0.05)$. The highest constant production rate of biomethane was observed for 300/60/15 $\left(k=0.246 \mathrm{~d}^{-1}\right)$ while the lowest for 400/60/15 ( $k$ $\left.=0.229 \mathrm{~d}^{-1}\right)$. Overall, 400/60/15 addition resulted in the worst kinetics, the $E B M P_{e}$ and $r$ were $334.22 \mathrm{mlcH}_{4} \mathrm{x} \mathrm{gvs}^{-1}$ and $76.36 \mathrm{mlcH}_{4} \times(\mathrm{gvs} \times \mathrm{d})^{-1}$ respectively. On the other hand, the best kinetics were obtained for 300/60/0 and 400/60/0 (Table 5). These results are a little confusing since the experiment showed that the highest methane production was for $400 / 60 / 0$ and HTC280, nevertheless, this is probably due to a simplification of the model, that was not able to take into account the increase in $\mathrm{CH}_{4}$ production after 17 days visible for HTC280 (Figure 1).

Table 5. Kinetic of $\mathrm{CH} 4$ production for all experiments

\begin{tabular}{|c|c|c|c|c|c|}
\hline Variant & No. & $k, d^{-1}$ & EBMP $_{\mathrm{e}}, \mathrm{mlcH} \mathrm{x} \mathrm{gvs}^{-1}$ & $\mathrm{r}, \mathrm{mlch}_{4} \mathrm{x}(\mathrm{gvs} \times \mathrm{d})^{-1}$ & $\mathbf{R}^{2},-$ \\
\hline \multirow{5}{*}{ Control } & 1 & 0.265 & 362.13 & 95.89 & 0.997 \\
\hline & 2 & 0.270 & 354.13 & 95.48 & 0.996 \\
\hline & 3 & 0.217 & 348.40 & 75.46 & 0.993 \\
\hline & 4 & 0.208 & 340.94 & 70.88 & 0.992 \\
\hline & Mean & 0.240 & 351.40 & 84.43 & 0.995 \\
\hline \multirow{5}{*}{$300 / 60 / 0$} & 1 & 0.266 & 357.43 & 95.25 & 0.996 \\
\hline & 2 & 0.264 & 357.42 & 94.29 & 0.996 \\
\hline & 3 & 0.205 & 357.16 & 73.31 & 0.995 \\
\hline & 4 & 0.202 & 343.32 & 69.23 & 0.993 \\
\hline & Mean & 0.234 & 353.83 & 83.02 & 0.995 \\
\hline \multirow{5}{*}{$300 / 60 / 15$} & 1 & 0.281 & 371.93 & 104.62 & 0.997 \\
\hline & 2 & 0.273 & 371.08 & 101.45 & 0.997 \\
\hline & 3 & 0.212 & 342.20 & 72.62 & 0.993 \\
\hline & 4 & 0.217 & 344.88 & 74.90 & 0.993 \\
\hline & Mean & 0.246 & 357.52 & 88.40 & 0.995 \\
\hline \multirow{5}{*}{$400 / 60 / 0$} & 1 & 0.249 & 377.05 & 93.77 & 0.996 \\
\hline & 2 & 0.268 & 368.88 & 98.99 & 0.996 \\
\hline & 3 & 0.200 & 356.88 & 71.20 & 0.994 \\
\hline & 4 & 0.222 & 347.68 & 77.29 & 0.994 \\
\hline & Mean & 0.235 & 362.62 & 85.31 & 0.995 \\
\hline \multirow{5}{*}{$400 / 60 / 15$} & 1 & 0.250 & 326.62 & 81.75 & 0.995 \\
\hline & 2 & 0.208 & 341.82 & 70.96 & 0.994 \\
\hline & 3 & - & - & - & - \\
\hline & 4 & - & - & - & - \\
\hline & Mean & 0.229 & 334.22 & 76.36 & 0.995 \\
\hline \multirow{5}{*}{ HTC280 } & 1 & 0.254 & 361.80 & 91.93 & 0.992 \\
\hline & 2 & 0.238 & 364.77 & 86.82 & 0.992 \\
\hline & 3 & 0.210 & 356.53 & 74.69 & 0.995 \\
\hline & 4 & - & - & - & - \\
\hline & Mean & 0.234 & 361.04 & 84.48 & 0.993 \\
\hline
\end{tabular}


Overall, the results of methane production kinetics were determined accurately. The maximum methane potential and process kinetic is highly dependent on substrate, inoculum, equipment, and process conditions such as TS and pH. Deepanraj et al. [52] analyzed the kinetic of biogas production from kitchen waste at different TS concentrations (5-15\%) and $\mathrm{pH}(5-9)$. The result of Deepanraj et al. [52] showed that first-order model kinetic (Gompertz model name by author) fit well to experimental data and had a determination coefficient $>0.994$. Moreover, results showed that the highest biogas production was obtained for $\mathrm{TS}=7.5 \%$ and $\mathrm{pH}$ of 7 [52]. Is worth noting that these values are close to the ones used in this study (TS varied from 6.53 to $6.59 \%$, and $\mathrm{pH}$ varied from 7.62 to 7.91 ). This suggests that those are important parameters for food waste anaerobic digesting and should be always considered when a BMP test of FW is prepared. There are pieces of evidence in the literature that biochar addition can improve anaerobic digestion of food waste e.g. by improving process stability, decreasing lag phase, increasing methane yield, e.t.c. Some theories described a process, how biochar enhances AD. Nevertheless, the abundance of food waste and used equipment/procedures lead to different AD enhancement results among studies. Bearing in mind that biochar production consumes energy, and biochar transport to biogas plant cost as well. Different low-temperature biochars that potentially could be made using residual heat from biogas combined heat and power unit $(\mathrm{CHP})\left(300-400{ }^{\circ} \mathrm{C}\right)$ were tested. It must be noted that biochars were made from a substrate used in a biogas plant, and added to reactors at only one low dose $\left(0.05 \mathrm{gBC} \times\right.$ g TSsubstrate $^{-1}$, or $\left.0.65 \mathrm{gBC}_{\mathrm{BC}} \mathrm{L}^{-1}\right)$. The application of different $\mathrm{BC}$ doses might influence biomethane production more significantly. It should be further investigated.

\section{Conclusions}

Executed experiments, on the application of biochar produced from the same substrate as used for the anaerobic digestion (food waste) under different low-temperature and pressure conditions, indicated that:

- not all low-temperature biochars at the presented dose can improve biomethane production yield;

- the biomethane yield changes are visible for extreme cases. The worst biochar led to an average $4.5 \% \mathrm{CH}_{4}$ decrease, while two of the best biochars increased $\mathrm{CH}_{4}$ production averagely by $3.5 \%$;

- biomethane production was improved averagely by $3.5 \%$ by biochar made at $400{ }^{\circ} \mathrm{C}$ in $60 \mathrm{~min}$ at atmospheric pressure, and by low-pressure hydrochar produced at 280 ${ }^{\circ} \mathrm{C}$, while the biodegradability of $\mathrm{FW}$ was higher than $81 \%$ in those variants;

- the theoretical $\mathrm{CH}_{4}$ potential of food waste was $460 \mathrm{mlcH}_{4} \times \mathrm{gvs}^{-1}$, while the first-order constant reaction rate was $k=0.24 \mathrm{~d}^{-1}$;

- the FW thermal treatment pressure may influence the EC of biochar.

Further researches are needed at low-temperature biochars since this study did not reveal clear the dependence between low-temperature biochars addition and methane production yield. More trials with different biochar production pressure variants, biochar doses, and at different food waste concentrations should be performed to the validity of the low-temperature biochar application in AD.

Supplementary Materials: The following are available online at www.mdpi.com/xxx/s1, Figure S1: title, Table S1: title, Video S1: title.

Author Contributions: Conceptualization, K.Ś., B.M., and A.B.; methodology, K.Ś.; software, K.Ś.; validation, K.Ś. formal analysis, B.M, P.T, K.Ś.; investigation, B.M.; resources, B.M.; data curation, K.Ś.; writing-original draft preparation, K.Ś, and B.M.; writing-review and editing, K.Ś., B.M., and A.B.; visualization, K.Ś.; supervision, A.B.; project administration, K.Ś, and A.B.; funding acquisition, B.M., and A.B.

Funding: The research was financed/co-financed under the individual student research project „Młode umysły - Young Minds Project" from the subsidy increased for the period 2020-2025 in the 
amount of $2 \%$ of the subsidy referred to Art. 387 (3) of the Law of 20 July 2018 on Higher Education and Science, obtained in 2019.

Data Availability Statement: All data derived during the experiments are given in the paper.

Conflicts of Interest: The authors declare no conflict of interest, and declare that the funders had no role in the design of the study; in the collection, analyses, or interpretation of data; in the writing of the manuscript, or in the decision to publish the results.

\section{Appendix A}

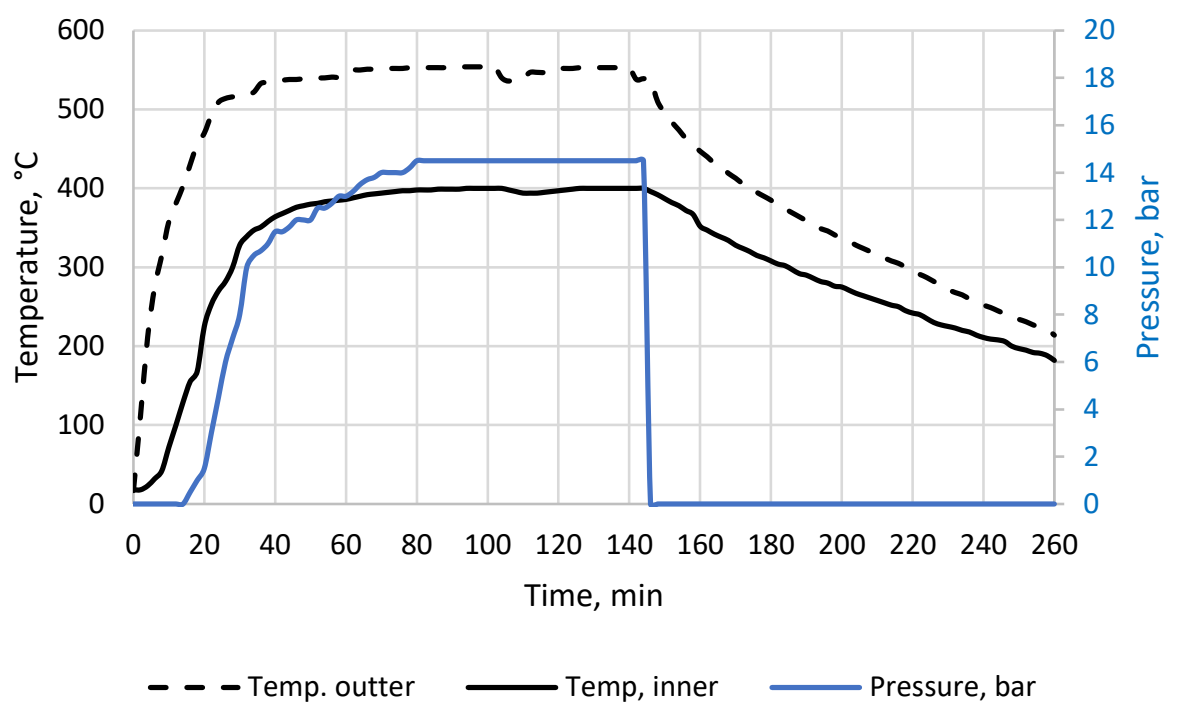

Figure A1. The biochar 400/60/15 production process, process parameters

\section{References}

1. $\quad$ Rockström, J.; Steffen, W.; Noone, K.; Persson, Å.; Chapin, F.S.; Lambin, E.; Lenton, T.M.; Scheffer, M.; Folke, C.; Schellnhuber, H.; et al. Planetary Boundaries: Exploring the Safe Operating Space for Humanity. Ecology and Society 2009, 14, 1-32. Available online: https://www.ecologyandsociety.org/vol14/iss2/art32/ (accessed on 29 November 2021).

2. Directive 2008/98/EC of the European Parliament and of the Council of 19 November 2008 on waste and repealing certain Directives. Available online: https://eur-lex.europa.eu/legal-content/EN/TXT/?uri=celex\%3A32008L0098 (accessed on 29 November 2021).

3. Store, J. Waste Management and Recycling: Council Adopts new Rules Available online: https:/www.consilium.europa.eu/en/press/press-releases/2018/05/22/waste-management-and-recycling-counciladopts-new-rules/\# (accessed on 29 November 2021).

4. European Environment Agency Bio-Waste in Europe-Turning Challenges into Opportunities. Available online: https://www.eea.europa.eu/publications/bio-waste-in-europe (accessed on 29 November 2021).

5. Połomka, J.; Jedrczak, A. Potential of Mineral Fraction in Compost-like-Output, Methods of Its Obtaining and the Possibility of Using It in the Context of Circular Economy. Materials 2020, 13, doi:10.3390/ma13133023.

6. Zamri, M.F.M.A.; Hasmady, S.; Akhiar, A.; Ideris, F.; Shamsuddin, A.H.; Mofijur, M.; Fattah, I.M.R.; Mahlia, T.M.I. A Comprehensive Review on Anaerobic Digestion of Organic Fraction of Municipal Solid Waste. Renewable and Sustainable Energy Reviews 2021, 137, doi:10.1016/j.rser.2020.110637.

7. Sarkar, S.; Pal, S.; Chanda, S. Optimization of a Vegetable Waste Composting Process with a Significant Thermophilic Phase. Procedia Environmental Sciences 2016, 35, 435-440, doi:10.1016/j.proenv.2016.07.026.

8. Sobieraj, K.; Stegenta-Dąbrowska, S.; Koziel, J.A.; Białowiec, A. Modeling of Co Accumulation in the Headspace of the Bioreactor during Organic Waste Composting. Energies 2021, 14, 1-17, doi:10.3390/en14051367. 
9. Stegenta-Dabrowska, S.; Sobieraj, K.; Koziel, J.A.; Bieniek, J.; Bialowiec, A. Kinetics of Biotic and Abiotic CO Production during the Initial Phase of Biowaste Composting. Energies 2020, 13, doi:10.3390/en13205451.

10. Bouallagui, H.; Cheikh, R. ben; Marouani, L.; Hamdi, M. Mesophilic Biogas Production from Fruit and Vegetable Waste in a Tubular Digester. Bioresource Technology 2003, 85-89. doi.org/10.1016/S0960-8524(02)00097-4.

11. Drosg, B. Process Monitoring in Biogas Plants; IEA Bioenergy, 2013; Available online: https://www.ieabioenergy.com/blog/publications/process-monitoring-in-biogas-plants/ (accessed on 29 November 2021).

12. Xu, F.; Li, Y.; Ge, X.; Yang, L.; Li, Y. Anaerobic Digestion of Food Waste - Challenges and Opportunities. Bioresource Technology 2018, 247, 1047-1058, doi:10.1016/j.biortech.2017.09.020.

13. Issah, A.A.; Kabera, T.; Kemausuor, F. Biogas Optimisation Processes and Effluent Quality: A Review. Biomass and Bioenergy 2020, 133, doi:10.1016/j.biombioe.2019.105449.

14. Qiu, L.; Deng, Y.F.; Wang, F.; Davaritouchaee, M.; Yao, Y.Q. A Review on Biochar-Mediated Anaerobic Digestion with Enhanced Methane Recovery. Renewable and Sustainable Energy Reviews 2019, 115, doi:10.1016/j.rser.2019.109373.

15. Chen, W.H.; Wang, C.W.; Ong, H.C.; Show, P.L.; Hsieh, T.H. Torrefaction, Pyrolysis and Two-Stage Thermodegradation of Hemicellulose, Cellulose and Lignin. Fuel 2019, 258, doi:10.1016/j.fuel.2019.116168.

16. Nizamuddin, S.; Baloch, H.A.; Griffin, G.J.; Mubarak, N.M.; Bhutto, A.W.; Abro, R.; Mazari, S.A.; Ali, B.S. An Overview of Effect of Process Parameters on Hydrothermal Carbonization of Biomass. Renewable and Sustainable Energy Reviews 2017, 73, 1289-1299.

17. Morales, V.L.; Pérez-Reche, F.J.; Hapca, S.M.; Hanley, K.L.; Lehmann, J.; Zhang, W. Reverse Engineering of Biochar. Bioresource Technology 2015, 183, 163-174, doi:10.1016/j.biortech.2015.02.043.

18. Dudek, M.; Świechowski, K.; Manczarski, P.; Koziel, J.A.; Białowiec, A. The Effect of Biochar Addition on the Biogas Production Kinetics from the Anaerobic Digestion of Brewers' Spent Grain. Energies 2019, 12, 1-22, doi:doi:10.3390/en12081518.

19. Valta, K.; Sotiropoulos, A.; Malamis, D.; Kosanovic, T.; Antonopoulou, G.; Alexandropoulou, M.; Jonuzay, S.; Lyberatos, G.; Loizidou, M. Assessment of the Effect of Drying Temperature and Composition on the Biochemical Methane Potential of In-House Dried Household Food Waste. Waste Management and Research 2019, 37, 461-468, doi:10.1177/0734242X18823943.

20. Matyjewicz, B.; Świechowski, K.; Koziel, J.A.; Białowiec, A. Proof-of-Concept of High-Pressure Torrefaction for Improvement of Pelletized Biomass Fuel Properties and Process Cost Reduction. Energies 2020, 13, 4790, doi:10.3390/en13184790.

21. Cai, J.; He, P.; Wang, Y.; Shao, L.; Lü, F. Effects and Optimization of the Use of Biochar in Anaerobic Digestion of Food Wastes. Waste Management \& Research: The Journal for a Sustainable Circular Economy 2016, 34, 409-416, doi:10.1177/0734242X16634196.

22. Sunyoto, N.M.S.; Zhu, M.; Zhang, Z.; Zhang, D. Effect of Biochar Addition on Hydrogen and Methane Production in Two-Phase Anaerobic Digestion of Aqueous Carbohydrates Food Waste. Bioresource Technology 2016, 219, 29-36, doi:10.1016/j.biortech.2016.07.089.

23. PN-EN 14346:2011 Standard. Waste Characteristics. Calculation of Dry Mass on the Basis of Dry Residue or Water Content. Available online: https://sklep.pkn.pl/pn-en-14346-2011p.html?options=cart (accessed on 29 November 2021).

24. PN-EN 15169:2011 Standard. Waste Characteristics. Determination of Organic Matter Content for Waste, Slurry and Sludge. Available online: https://sklep.pkn.pl/pn-en-15169-2011p.html (accessed on 29 November 2021).

25. PKN ISO/TS 12902 :2007 Solid Mineral Fuel - Determination of Total Carbon, Hydrogen and Nitorgen - Instrumental Methods. Available online: https://sklep.pkn.pl/pkn-iso-ts-12902-2007p.html?options=cart (accessed on 29 November 2021). 
26. Achinas, S.; Euverink, G.J.W. Theoretical Analysis of Biogas Potential Prediction from Agricultural Waste. ResourceEfficient Technologies 2016, 2, 143-147, doi:10.1016/j.reffit.2016.08.001.

27. Zhang, Y. Anaerobic Digestion Fundamentals II Thermodynamics; Jyväskylä , 2013; Available online: http://www.valorgas.soton.ac.uk/Pub docs/JyU\%20SS\%202013/VALORGAS JyU 2013 Lecture\%202.pdf (accessed on 29 November 2021).

28. Orangun, A.; Kaur, H.; Kommalapati, R.R. Batch Anaerobic Co-Digestion and Biochemical Methane Potential Analysis of Goat Manure and Food Waste. Energies 2021, 14, doi:10.3390/en14071952.

29. Stępień, P.; Serownik, M.; Koziel, J.A.; Bialowiec, A. Waste to Carbon: Estimating the Energy Demand for Production of Carbonized Refuse-Derived Fuel. Sustainability 2019, 11, doi:doi:10.3390/su11205685.

30. Kumar, M.; Dutta, S.; You, S.; Luo, G.; Zhang, S.; Show, P.L.; Sawarkar, A.D.; Singh, L.; Tsang, D.C.W. A Critical Review on Biochar for Enhancing Biogas Production from Anaerobic Digestion of Food Waste and Sludge. Journal of Cleaner Production 2021, 305, 127143, doi:10.1016/j.jclepro.2021.127143.

31. Codignole Luz, F.; Cordiner, S.; Manni, A.; Mulone, V.; Rocco, V. Biochar Characteristics and Early Applications in Anaerobic Digestion-a Review. Journal of Environmental Chemical Engineering 2018, 6, $2892-2909$. doi.org/10.1016/j.jece.2018.04.015.

32. Zatorska, J. Badania Porowatych Materiałów Węglowych Otrzymywanych Poprzez Karbonizację Poli (Tereftalanu Etylenu) w Mieszaninie z Wybranymi Związkami Magnezu, PhD thesis, Szczecin, 2013. Available online: https://zbc.ksiaznica.szczecin.pl/dlibra/publication/31080/edition/29484?language=en (accessed on 29 November 2021).

33. Zdravkov, B.D.; Čermák, J.J.; Šefara, M.; Janků, J. Pore Classification in the Characterization of Porous Materials: A Perspective. Central European Journal of Chemistry 2007, 5, 385-395, doi:10.2478/s11532-007-0017-9.

34. Xu, M.; Li, D.; Yan, Y.; Guo, T.; Pang, H.; Xue, H. Porous High Specific Surface Area-Activated Carbon with Co-Doping N, S and P for High-Performance Supercapacitors. RSC Advances 2017, 7, 43780-43788, doi:10.1039/c7ra07945a.

35. Gaffar, S.; Dattamudi, S.; Baboukani, A.R.; Chanda, S.; Novak, J.M.; Watts, D.W.; Wang, C.; Jayachandran, K. Physiochemical Characterization of Biochars from Six Feedstocks and Their Effects on the Sorption of Atrazine in an Organic Soil. Agronomy 2021, 11, 716, doi:10.3390/agronomy11040716.

36. Cruz Viggi, C.; Simonetti, S.; Palma, E.; Pagliaccia, P.; Braguglia, C.; Fazi, S.; Baronti, S.; Navarra, M.A.; Pettiti, I.; Koch, C.; et al. Enhancing Methane Production from Food Waste Fermentate Using Biochar: The Added Value of Electrochemical Testing in Pre-Selecting the Most Effective Type of Biochar. Biotechnology for Biofuels 2017, 10, 303, doi:10.1186/s13068-017-0994-7.

37. Chen, S.; Rotaru, A.-E.; Liu, F.; Philips, J.; Woodard, T.L.; Nevin, K.P.; Lovley, D.R. Carbon Cloth Stimulates Direct Interspecies Electron Transfer in Syntrophic Co-Cultures. Bioresource Technology 2014, 173, 82-86, doi:10.1016/j.biortech.2014.09.009.

38. Gabhi, R.S.; Kirk, D.W.; Jia, C.Q. Preliminary Investigation of Electrical Conductivity of Monolithic Biochar. Carbon 2017, 116, 435-442, doi:10.1016/j.carbon.2017.01.069.

39. Hoffmann, V.; Rodriguez Correa, C.; Sautter, D.; Maringolo, E.; Kruse, A. Study of the Electrical Conductivity of Biobased Carbonaceous Powder Materials under Moderate Pressure for the Application as Electrode Materials in Energy Storage Technologies. GCB Bioenergy 2019, 11, 230-248, doi:10.1111/gcbb.12545.

40. Singh, B.; Dolk, M.M.; Shen, Q.; Arbestain, M.C. Biochar PH, Electrical Conductivity and Liming Potential. In Biochar: A Guide to Analytical Methods; Singh, B., Camps-Arbestain, M., Lehmann, J., Eds.; CRC Press, 2017; pp. 23-38. Available online: https://www.researchgate.net/publication/319206365 (accessed on 29 November 2021).

41. Banks, C.; Heaven, S.; Zhang, Y.; Baier, U. Food Waste Digestion: Anaerobic Digestion of Food Waste for a Circular Economy; IEA Bioenergy, 2018; ISBN 9781910154588. Available online: https://www.ieabioenergy.com/blog/publications/foodwaste-digestion-anaerobic-digestion-of-food-waste-for-a-circular-economy/ (accessed on 29 November 2021). 
42. Chen, T.-H.; Hashimoto, A.G. Effects of PH and Substrate:Inoculum Ratio on Batch Methane Fermentation. Bioresource Technology 1996, 56, 179-186, doi:10.1016/0960-8524(96)00016-8.

43. Mao, C.; Feng, Y.; Wang, X.; Ren, G. Review on Research Achievements of Biogas from Anaerobic Digestion. Renewable and Sustainable Energy Reviews 2015, 45, 540-555, doi:10.1016/j.rser.2015.02.032.

44. Kim, J.; Park, C.; Kim, T.-H.; Lee, M.; Kim, S.; Kim, S.-W.; Lee, J. Effects of Various Pretreatments for Enhanced Anaerobic Digestion with Waste Activated Sludge. Journal of Bioscience and Bioengineering 2003, 95, 271-275, doi:10.1016/S13891723(03)80028-2.

45. Lee, D.H.; Behera, S.K.; Kim, J.W.; Park, H.-S. Methane Production Potential of Leachate Generated from Korean Food Waste Recycling Facilities: A Lab-Scale Study. Waste Management 2009, 29, 876-882, doi:10.1016/j.wasman.2008.06.033.

46. Zhang, P.; Chen, Y.; Zhou, Q. Waste Activated Sludge Hydrolysis and Short-Chain Fatty Acids Accumulation under Mesophilic and Thermophilic Conditions: Effect of PH. Water Research 2009, 43, 3735-3742, doi:10.1016/j.watres.2009.05.036.

47. Dinamarca, S.; Aroca, G.; Chamy, R.; Guerrero, L. The Influence of PH in the Hydrolytic Stage of Anaerobic Digestion of the Organic Fraction of Urban Solid Waste. Water Science and Technology 2003, 48, 249-254, doi:10.2166/wst.2003.0409.

48. Fang, H.H.P.; Liu, H. Effect of PH on Hydrogen Production from Glucose by a Mixed Culture. Bioresource Technology 2002, 82, 87-93, doi:10.1016/S0960-8524(01)00110-9.

49. Klein, R.; Slaný, V.; Krčálová, E. Conductivity Measurement for Control of a Biogas Plant. Acta Universitatis Agriculturae et Silviculturae Mendelianae Brunensis 2018, 66, 1151-1156, doi:10.11118/actaun201866051151.

50. Xue, B.; Zifu, L.; Xuemei, W.; Xi, H.; Shikun, C.; Xiaofeng, B.; Ruiling, G. Online Measurement of Alkalinity in Anaerobic Co-Digestion Using Linear Regression Method. International Journal of Agricultural and Biological Engineering 2017, 10, 176-183, doi:10.3965/j.ijabe.20171001.2701.

51. Filer, J.; Ding, H.H.; Chang, S. Biochemical Methane Potential (BMP) Assay Method for Anaerobic Digestion Research. Water 2019, 11, 921, doi:10.3390/w11050921.

52. Deepanraj, B.; Sivasubramanian, V.; Jayaraj, S. Experimental and Kinetic Study on Anaerobic Digestion of Food Waste: The Effect of Total Solids and PH. Journal of Renewable and Sustainable Energy 2015, 7, 063104, doi:10.1063/1.4935559. 